\title{
The Design of Informatization of Urology Education
}

\author{
Jin-guo Wang ${ }^{1}$, and Na Wang ${ }^{2, *}$ \\ ${ }^{1}$ Department of Urology, The First Hospital of Jilin University, China \\ ${ }^{2}$ Department of Anesthesiology, The First Hospital of Jilin University, China \\ ${ }^{*}$ Corresponding author
}

Keywords: Information Technology, Urology, Education.

\begin{abstract}
Application of information technology in education is an inevitable trend of modern medical education. On the base of the characteristics and knowledge structure of urinary, we analyze information alization of urology education on the aspects of classroom teaching and network teaching. Through the application of computer technology, a virtual bank of tissue biopsies, urological multimedia courseware and interaction platform should be built.
\end{abstract}

\section{Introduction}

It is generally believed that in the good network learning environment, students are able to conduct various learning activities, including browsing, evaluation and interaction. Browse the learning activity refers to learners use a browser, according to the study demand, active reading all kinds of learning resources on the Internet, assessment of learning activity refers to the students in the learning process, fully using the online test, homework way to check your current study effect [1]. It refers to the interactive learning activities between students and teachers to assist, discussion and other activities. Teaching is the main body and core of teaching of undergraduate course, the course information as the main focus of deepening the reform of information technology teaching, is using the law of higher education teaching, grasp the main contradiction main measures of reform.

\section{The Teaching in Lecture Class}

To meet the students' autonomous learning, teacher's personal teaching guidance and teaching interactive activities, specific to the outside of the urinary lessons, and have its special place. Urology is medical professional backbone course, its research object is human body disease state organs and tissues of the specimens, the research content is to observe the pathological changes of organs and tissues, including the types and characteristics of the lesions, development rule and the connection with clinical manifestations, etc [2]. According to the characteristics of the above, we will be outside the urinary information teaching design in two parts: classroom teaching and network teaching.

With the continuous development of modern science and technology, represented by the human genome project research frontier of medical science and technology development and breakthrough, herald the arrival of a new round of revolution in medicine. The transformation of medical model, the concept of five-star doctor ecological environment problems such as imbalance and the aging of the population, to the cultivation of high-level medical talents and hospital discipline construction put forward new and higher requirements. Subject construction in hospital, clinical discipline is the most important technology of hospital resources, as well as the most concentrated endogenous health resource, the most active parts [3].

Learning outside the urinary mainly by the naked eye and optical microscope for organ specimens and tissue samples to conduct a comprehensive and meticulous observation, discover pathological changes, therefore, we apply computer technology to construct the virtual tissue biopsies, digital gross library and urological multimedia courseware. 


\section{The Virtual Biopsy Library}

It can intercept the typical pathological changes of static images for students to discuss, to help students in the little while to find the right lesions, and guide students to accurately understand the pathological changes, grasp the characteristics of pathological changes, and for the interpretation of microscopic lesions more intuitive and more clearly [4].

Gross specimens were all gross specimen made into a digital photos into the computer. Gross specimen source is very valuable, has the characteristics of uniqueness in use, no two samples is the same, so can't let the students handle the same specimens, observation alone. Because the quantity of samples and the observation of space and time limit, causes the student to the gross learning is often inadequate [5].

With the rapid development of information technology, network, the integration of information technology and college English curriculum fundamentally changed the nature of college English teaching, college English classroom teaching from traditional classroom to modern network environment of college English classroom [6]. The college English curriculum requirements issued by the ministry of education explicitly put forward the based on the computer and the classroom college English teaching model.

\section{The Urological Multimedia Platform}

In the traditional school education, learners and teachers can significantly realize the learners' differences in learning motivation, learning interest, but for learners in such aspects as knowledge structure and learning habit of difference is not enough. In digital learning such as online learning and mobile learning, the students can easily record the visited web sites, read the study content, thus analysis and sums up the learners' knowledge structure and study habits [7]. Network learning and mobile learning for the application of environmental learning theory in the teaching of arteries and veins provides technical basis, and in pulse learning theory as the theoretical basis is provided for the development of mobile learning.

\section{The Network Teaching}

Network teaching is based on our university campus network platform, including two parts: urinary outside network course and online interactive teaching system. Optimized hardware environment construction and services, diversification and the concept of ecological software environment, puts forward the ecological integrated multiple curriculum evaluation system construction, ecological diversity and individuation of teaching resources, platform construction, etc. Based on the educational reform pattern of college English classroom teaching in disorder phenomenon as the breakthrough point, on the basis of the empirical and theoretical strive to build an ecological optimization framework of college English classroom teaching [8]. In this paper, research on the current network environment for the improvement of college English classroom teaching quality, the improvement of the teaching reform mode, with the actual reference and reference value for students' lifelong learning.

\section{Autonomous Learning}

The original memory and learning to the learners themselves constitute the inner world of the complete reaction, learners, when dealing with new information or knowledge meaning to their inner world that is to learn. Teachers in clinical practice teaching use the right methods. It will be required by the medical ethics right values into every classroom teaching, strengthen the communication with students and to include women undergoing surgical department of urology, development direction and prospects of discussion, will provoke interest, including female students, interns, received good results [9]. In pulse learning theory assumes that the brain instinctively to search for meaning in the condition of arteries and veins, namely in the learners' environment and search for the processing of 
new information or new knowledge and their internal relations between meaning or seemingly useful world.

\section{The Interactive Teaching System for Teachers}

Online interactive teaching goal is communication and development, and in a timely manner to give guidance to students, improve their observation, the ability to analyze and solve problems. In order to actively and in-depth information technology teaching of medical students, our school set up the online teaching system [10]. The web page form will be all kinds of network teaching resources existing in our school, carried out in accordance with the teachers and students use process organic integration. Online interactive teaching system with the method which enables the students and teachers to instant communication, information feedback, through text chat/white in answering questions, discussion, homework, tests, and other teaching activities.

Teachers according to students' learning situation and learning Settings targeted learning guidance, set a specific course for student counseling, to ensure the effect of students' learning. Like to read for a classroom teaching target network curriculum resources, or don't understand the problem through the network communication platform to seek the help of the teacher or a classmate, or the common difficult to discuss, let the student to respond to their own opinions, such interactions can help students with learning difficulties and improve the learning interest.

\section{The Interactive Teaching System for Students}

Teaching in the online system, network support, then, provides a more convenient way of new interaction between people, provides a variety of media interaction platform, adding the interaction between the students. In our teaching practice, the organic integration of classroom teaching and network teaching, fully implement the deepening of the teaching content, not only ensuring the quality of students as a group, and inspired the students as individuals interested in knowledge of self-discovery [11]. The combination of the two effectively shortens the learning time, improve the teaching quality and teaching efficiency, achieve the most optimization of the teaching goal. Due to urinary outside learn knowledge characteristic and teaching mode, the information teaching has been widely used in urinary learning teaching process. Believe it broad space for development and prospects will attract people to constantly on various attempt and exploration.

\section{Conclusions}

Digital and information-based teaching effectively implement student-centered interaction between teachers and students, adapting to the socialization of medical education to lifelong education, the innovation quality education and student-centered education the need of the change of the pattern.

\section{References}

[1] Schlager M, Fusco J., Schank P. Evolution of an online education community of practice. 2002

[2] Lotan Y, Gettman MT. The new economics of radical prostatectomy: cost comparison of open, laparoscopic and robot assisted techniques. Journal d Urologie. 2004

[3] Ahlering TE, Eichel L, Edwards R, et al. Robotic radical prostatectomy: A technique to reduce pT2 Margins. Urolog . 2004

[4] Wiklund NP. Technology insight: Surgical robots-Expensive toys or the future of urologic surgery. Nat Clin Pract Urol. 2004

[5] Ahlering TE, Woo D, Eichel L, et al. Robot assisted vs. open prostatectomy: A comparison of one surgeon's outcomes. Urology. 2004 
[6] Basillotte J, Ahlering TE, Skarecky DW, et al. Laparoscopic radical prostatectomy: Review and assessment of an emerging technique. Surgical Endoscopy. 2004

[7] Surveillance, Epidemiology, and End Results (SEER) Program. SEER Stat Database: Incidence SEER 9 Regs Limited-Use, Nov 2006 Sub (1973-2004). http://www.seer.cancer.gov. 2007

[8] Van Velthoven R, Ahlering TE, Peltier A, et al. Technique for laparoscopic running urethrovesical anastomosis: The single knot method. Urology. 2003

[9] Pasticier G, Rietbergen JB, Guillonneau B, Fromont G,Menon M,Vallancien G.Robotically assisted laparoscopic radical prostatectomy: feasibility study in men. European Urology . 2001

[10] Ahlering TE, Douglas S, Lee D, Clayman RV. Successful transfer of open surgical skills to a laparoscopic environment using a robotic interface: initial experience with laparoscopic radical prostatectomy. Journal d Urologie. 2003

[11] Ficarra V, Cavalleri S, Novara G,Aragona M, Artibani W. Evidence from robot-assisted laparoscopic radical prostatectomy: a systematic review. European Urology. 2007 